Article

\title{
Geoheritage at the Equator: Selected Geosites of São Tomé Island (Cameron Line, Central Africa)
}

\section{Maria Helena Henriques ${ }^{1, *}$ and Keynesménio Neto ${ }^{2}$}

1 Department of Earth Sciences and Geosciences Centre, Faculty of Sciences and Technology, University of Coimbra (Polo II), Rua Sílvio Lima, 3030-790 Coimbra, Portugal

2 Instituto Superior de Educação e Comunicação, University of São Tomé e Príncipe and Geosciences Centre, Faculty of Sciences and Technology, University of Coimbra, Rua Padre Martinho Pinto da Rocha, No. 939, Caixa Postal No. 300, São Tomé e Príncipe, 3030-790 Coimbra, Portugal; E-Mail: keynesmenio@gmail.com

* Author to whom correspondence should be addressed; E-Mail: hhenriq@dct.uc.pt; Tel.: +351-239-860-510; Fax: +351-239-860-501.

Academic Editor: Marc A. Rosen

Received: 2 December 2014 / Accepted: 30 December 2014 / Published: 7 January 2015

\begin{abstract}
This work presents, for the first time, an overview of the rich geodiversity outcropping in the São Tomé island, one of the two islands that make up the archipelago of São Tomé and Príncipe, the second smallest state of Africa in area. Located at the equator, in the alignment known as the "Cameroon Volcanic Line", this archipelago represents a privileged area for the comparative study between oceanic and continental alkaline volcanism, and therefore between the subcontinental and suboceanic mantle. Ten geosites of São Tomé island were selected, described and evaluated on the basis of their geoheritage value and using a qualitative system of classification, which integrates both the meaning attributed to the objects by scientific communities and the public understanding of such meanings related to its social use. The selected geosites display different heritage values (documental, scenic, symbolic, iconographic and indicial) potentially usable for different purposes, namely scientific and educational, but mostly tourism. Geotourism can play a key role in the promotion of sustainable development in the Democratic Republic of São Tomé and Príncipe, and the geosites here described are likely to ground a geo-itinerary on this "pearl" of the Cameron Line.
\end{abstract}


Keywords: geomorphological heritage; geotourism; geo-itinerary; São Tomé island; Cameroon Volcanic Line; African Alive Corridors

\section{Introduction}

The island of São Tomé makes up, with the island of Príncipe and some small islets, the tiny archipelago of São Tomé and Príncipe, and the second smallest state of Africa in area. This archipelago consists of intra-plate volcanic islands, representing part of the oceanic sector of a major volcanic alignment known as the "Cameroon Volcanic Line", which is a privileged area for the comparative study between oceanic and continental alkaline volcanism, and therefore between the subcontinental and suboceanic mantle [1,2].

The "Cameroon Volcanic Line" configures a linear chain of islands angling across the Gulf of Guinea to meet an arc of peaks curving through Cameroon. It represents a unique geological-topographic structure traversing both ocean and continent - the "African Pole of Rotation", one of the 20 "African Alive Corridors" that provide specific milestones to reconstruct and tell the Africa's autobiography [3]. Systematic studies on the geoheritage values of the Cameron Line are limited to Mount Manengouba, a volcanic complex located at Cameroon, recently analysed in terms of geomorphological heritage in order to support a future geopark [4]. Like "pearls along a necklace", both São Tomé and Príncipe islands are part of one chapter of such story, entitled "Africa across the Cameroon Hot Line", which happened during the last $200 \mathrm{Ma}$, and is recorded from Nigeria to Pagalu island. As such, they represent two Heritage Nodes ("18-Einstein's Theory of Relativity" and "19-2nd smallest African country" of the Corridor), that offer wide potential to be developed from a geotouristic perspective, thus ensuring the physical integrity of their geological heritage and supporting sustainable development initiatives [5].

However, like in many other countries of Africa, where geoconservation has a very poor record [6], the nature conservation policies implemented in the Democratic Republic of São Tomé and Príncipe are circumscribed to biodiversity conservation concerns. The isle of Príncipe, declared as a Biosphere Reserve of the UNESCO's Man and the Biosphere Programme since 2012, represents an example of such generalized unbalanced perception of nature [7], despite being the oldest of the three existing oceanic volcanic islands of the Gulf of Guinea, formed 31 million years ago [8].

Biodiversity in the Gulf of Guinea islands is of great interest to conservationists and evolutionary biologists, namely the Príncipe and São Tomé islands, where species endemism display unusually high values ( $8 \%$ for plants and $100 \%$ for amphibians, and 14\% for plants and $100 \%$ for amphibians, respectively) [9]. The São Tomé avifauna, which includes rare endemic species, also represents an attraction to specialist tours on natural history and bird watching, and can place an economic value on the island's forests and wildlife if local tourism industry is responsibly managed [10]. Geotourism can add to ecotourism's principal focus on plants (flora) and animals (fauna) by integrating a third dimension of the abiotic environment: the geological heritage [11] in its broadest sense (i.e., volcanic heritage, geomorphological heritage, mineralogical heritage, hydrogeological heritage, paleontological heritage, etc. as examples of types of geoheritage where scientific knowledge inherent to basic geoconservation can be applied [12]). 
The main goal of this work is to present, for the first time, an overview of the rich geodiversity outcropping in the São Tomé island, by describing 10 selected geosites with heritage value-including those landform to which a value can be attributed, i.e., geomorphosites [13] — which can ground a geo-itinerary on this "pearl" of the Cameron Line.

Taking into account the role that geoconservation materials and products can play in science, education and geotourism, this work aims at contributing to and supporting on-going initiatives addressing the need of intensifying geo-education actions within the African continent [14], namely among the Community of Portuguese-Speaking Countries [15].

\section{Geological Setting and Geosites Selection}

The island of São Tomé is located in the Gulf of Guinea, $2 \mathrm{~km}\left(1 \frac{1 / 4}{4}\right.$ miles $)$ north of the equator-between latitudes $0^{\circ} 24^{\prime} 39.78^{\prime \prime} \mathrm{N} ; 6^{\circ} 43^{\prime} 2.38^{\prime \prime} \mathrm{E}$ and $0^{\circ} 0^{\prime} 46.37^{\prime \prime} \mathrm{S} ; 6^{\circ} 30^{\prime} 58.79^{\prime \prime} \mathrm{E}$ (islet of Rolas) - and has an area of $857 \mathrm{~km}^{2}$ (Figure 1). It rises from about $3000 \mathrm{~m}$ depth to the altitude of 2024 $\mathrm{m}$ at Pico de São Tomé, and has a large submarine platform, bounded by the $200 \mathrm{~m}$ isobath, of approximately $450 \mathrm{~km}^{2}$.

The São Tomé island displays a NE-SW oblong configuration, with $46 \mathrm{~km}$ of major axis and $34 \mathrm{~km}$ of minor axis, aligned with the approximate orientation of "the Cameroon Volcanic Line". It is mainly composed of volcanic rocks representing four main volcano-stratigraphic units (Figure 2): the São Tomé Volcanic Complex ( $<1.5 \mathrm{Ma}$ ); the Phonolitic Basaltic Complexes, which include the Volcanic Complex of Ribeira Afonso (2.5-5 Ma) and the Volcanic Complex of Mizambú (7-8 Ma); and the Volcanic Formation of Ilhéu das Cabras (13 Ma) [1,2,16-21]. Some of these volcano-stratigraphic units are particularly well represented through volcanic landforms of great visual impact, but others display other features with heritage value, which must be considered as geological elements with exceptional scientific, educational, touristic or cultural value, i.e., as geosites [12].

Different methods and techniques of inventory and evaluation of geosites are currently used to select geosites for geoconservation purposes, based on qualitative ([12] and references therein) and/or quantitative ([22] and references therein) systems of classification of the geoheritage value displayed by geological objects. Beyond the diverse properties usually recognized by geoscientists, other criteria, such as those related to the social role attributed to geological objects by communities outside earth scientists (e.g., conservationists or people in the tourist sector [23]), should also be considered in geoconservation procedures [7].

A qualitative system of classification of the geological heritage based on its content has been already proposed and reasoned in detail [24]. The content of a geological object with heritage value can be described through a set of concepts controlled by variable factors which depend both on the meaning attributed to the objects by scientific communities (defined as "relevance grade" and ranging from local to global) and the public understanding of such meanings related to its social use (defined as "abstract perceptiveness", which ranges from individual to social scale).

Such open system was recently applied to other geosites located in African countries where there is no legislation on geoconservation and/or there is little public awareness of geoconservation; its use can be quite helpful to supplement the existing nature conservation status of areas already legally protected for reasons other than geological ones, as it frequently happens in Africa [25]. 
In this work, the selection of geosites were based on the above mentioned criteria, i.e., on the heritage contents they display, which can be ranked into three categories of increasing importance: rank I-indicial contents (assigned to geological objects exhibiting clear relation between elementary geological processes and their resulting products); rank II-documental, iconographic, and symbolic contents; and rank III—conceptual and scenic contents [24].

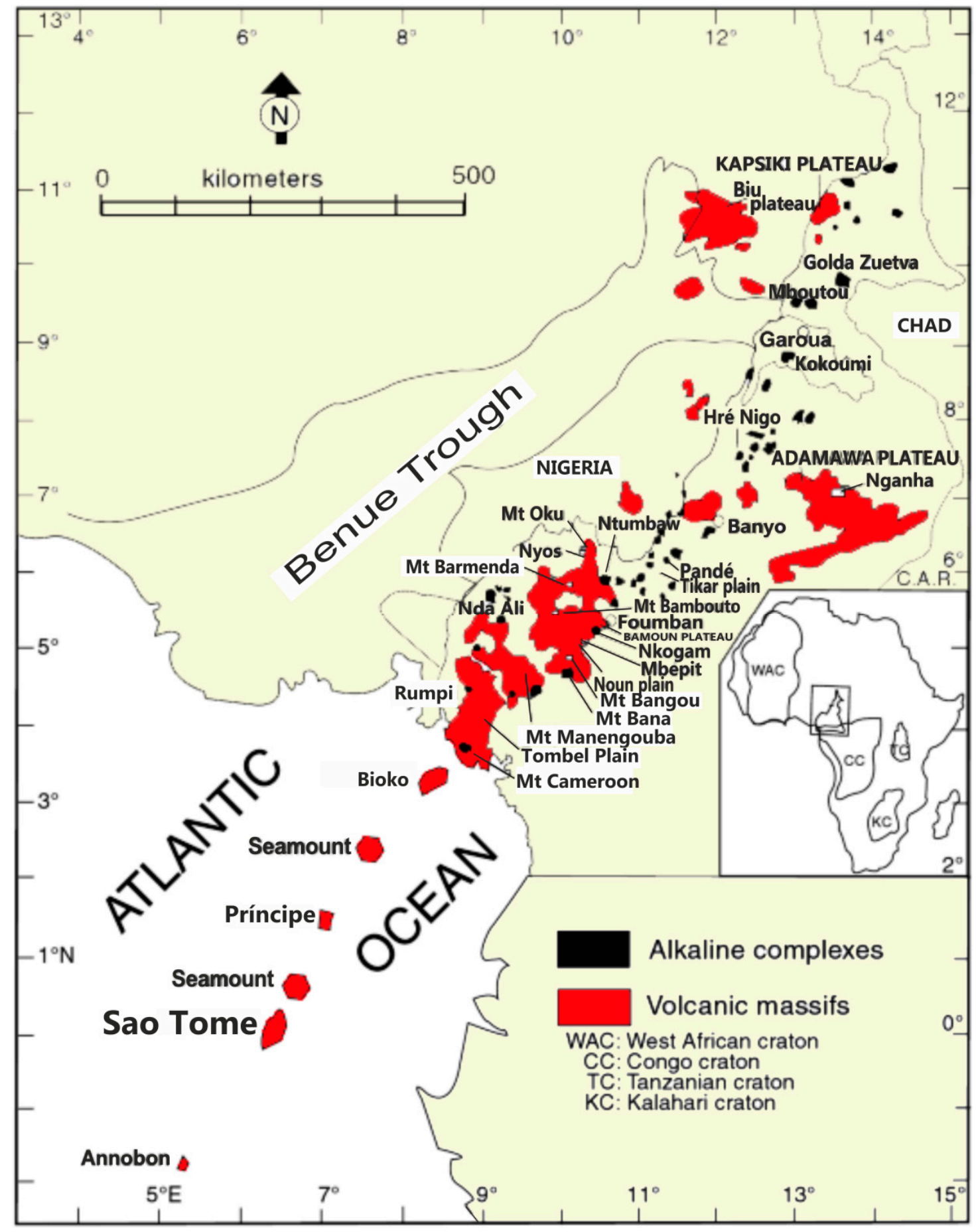

Figure 1. Geographic location and geological setting of São Tomé island within the "Cameroon Volcanic Line" of West Central Africa, where alkaline complexes of plutonic origin co-occur with Cenozoic volcanic structures [16]. Reproduced with permission from the Geological Society of America, 2014. 


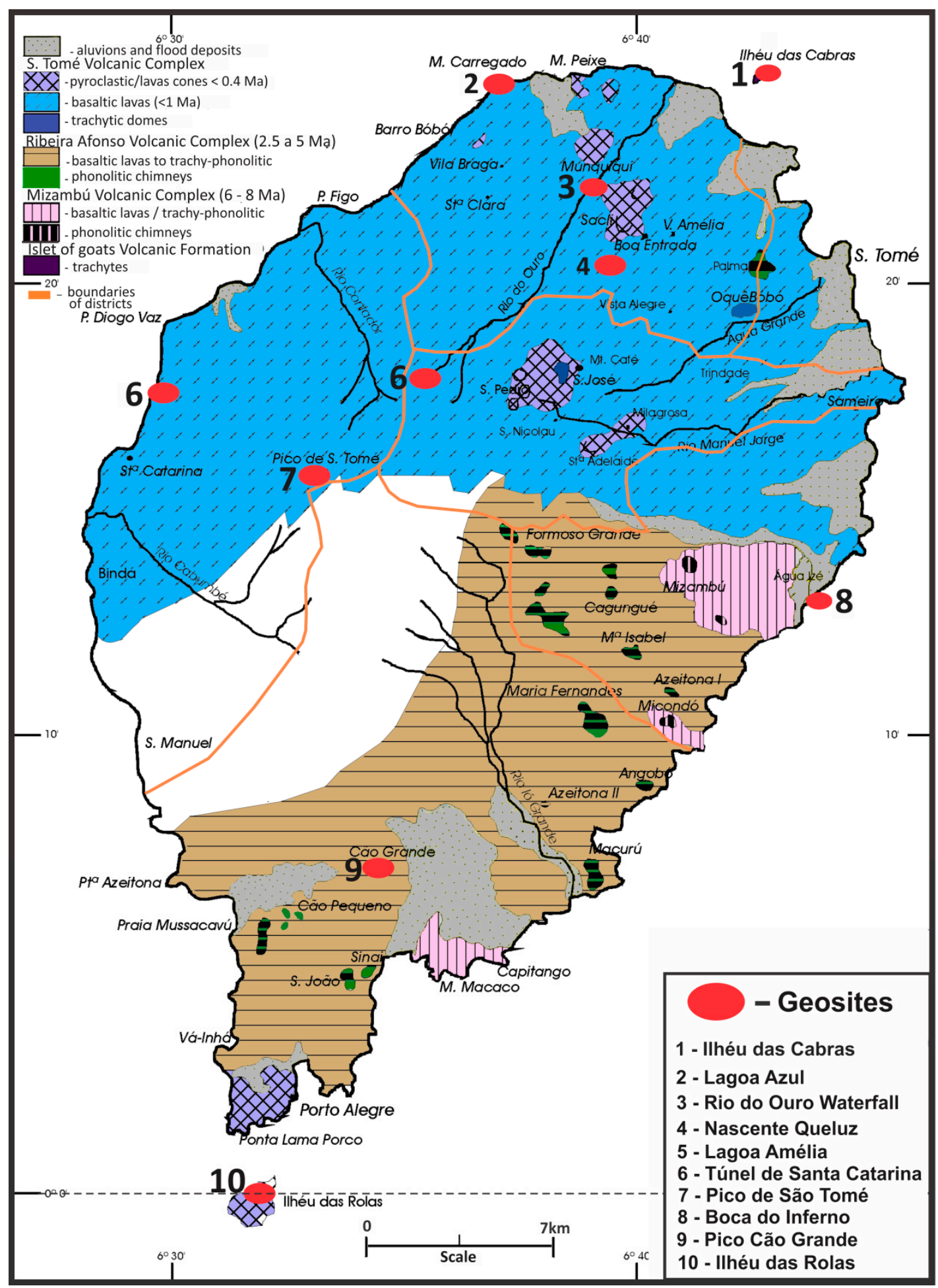

Figure 2. Geological map of São Tomé island and location of the selected geosites (modified after Caldeira et al., 2013 [20]).

\section{Results and Discussion}

The selected geosites of São Tomé to be considered under a geoconservation perspective include geological objects displaying different contents and representing different types of geoheritage (Table 1). Some of them are assignable to more than one type of content, which increases its global heritage value and justifies the adoption of measures aimed at its geoconservation. 
Table 1. Types of geoheritage recognizable at São Tomé island.

\begin{tabular}{ll}
\hline \multicolumn{1}{c}{ Geosites } & \multicolumn{1}{c}{ Type of Geoheritage } \\
\hline (1) Cascata do Rio do Ouro & Geomorphological; Volcanological \\
(2) Boca do Inferno & Volcanological \\
(3) Pico do Cão Grande & Geomorphological; Volcanological \\
(4) Lagoa Azul & Geomorphological; Volcanological \\
(5) Nascente Queluz & Hydrogeological \\
(6) Lagoa Amélia & Geomorphological; Volcanological \\
(7) Ilhéu das Rolas & Geomorphological; Volcanological \\
(8) Túnel de Santa Catarina & Volcanological \\
(9) Ilhéu das Cabras & Volcanological \\
(10)Pico de São Tomé & Geomorphological; Volcanological \\
\hline
\end{tabular}

\subsection{Cascata do Rio do Ouro}

The Cascata do Rio do Ouro ("Rio do Ouro waterfall") is located inside the Agostinho Neto farm, formerly known as Rio do Ouro, one of the most extensive plantations or "roça" settled during the 19th century by the Portuguese (Lobata district; coordinates $0^{\circ} 22^{\prime} 22.90^{\prime \prime} \mathrm{N} ; 6^{\circ} 38^{\prime} 53.40^{\prime \prime} \mathrm{E}$ ). The waterfall is approximately $15 \mathrm{~m}$ high and it flows along a $30 \mathrm{~m}$ width outcrop showing well developed columnar disjunction; nearby, it is also possible to observe laminated basaltic rocks, all representing the São Tomé Volcanic Complex [20] (Figure 3).

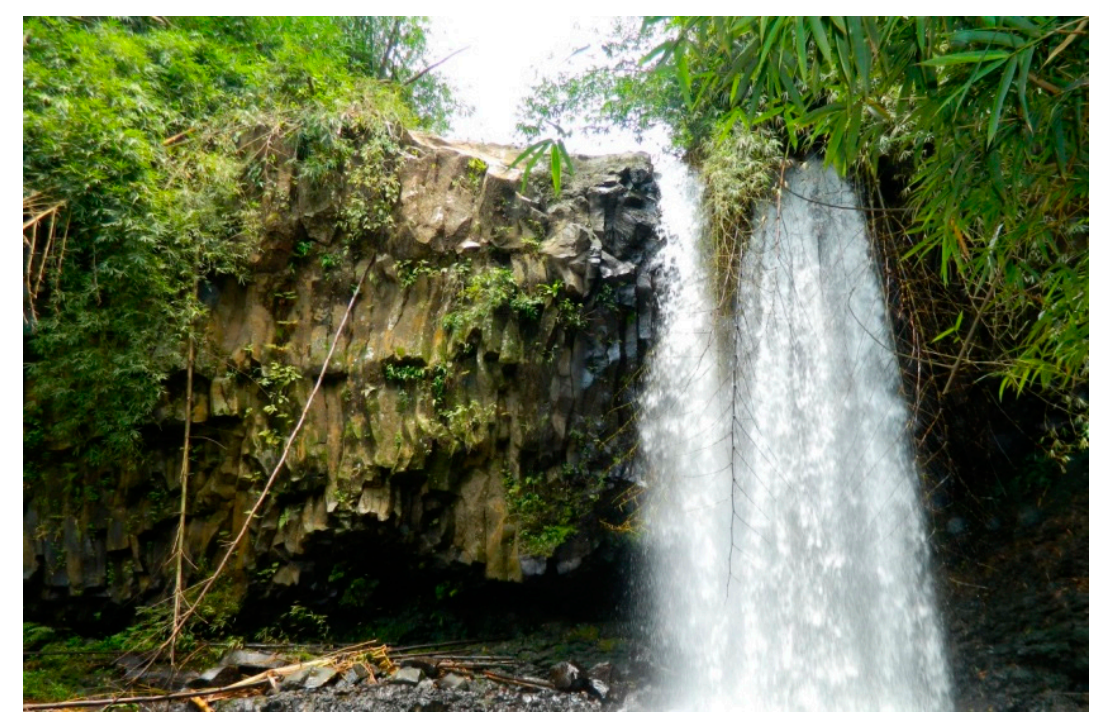

Figure 3. Rio do Ouro waterfall showing columnar disjunction of the São Tomé Volcanic Complex.

These volcanic features represent the retraction in all directions of lavas experiencing a slow cool-down, resulting in a hexagonal pattern due to the homogeneity of the rock and gradient of heat loss. By corresponding to a highly demonstrative record particularly relevant for the understanding of significant geologic changes assigned to a region, such geometrical features display documental value, which is complemented by the highly recreational function of the waterfall, which corresponds to scenic value [24]. 


\subsection{Boca do Inferno}

The Boca do Inferno geosite is located at Cantagalo District (coordinates $0^{\circ} 12^{\prime} 48.26^{\prime \prime} \mathrm{N}$; $6^{\circ} 43^{\prime} 34.97^{\prime \prime} \mathrm{E}$ ) and is a small channel resulting from marine erosion of basaltic lavas of the São Tomé Volcanic Complex [20] (Figure 4). Columnar disjunction and pillow lavas are typical volcanic features well represented along the shoreline, which represent documental value. The characteristic pillow-shaped structures of the pillow lavas suggest their origin in an obvious way, i.e., the extrusion of the lava under water. By exhibiting clear relation between elementary geological processes and their resulting products, the presence of these volcanic structures can support the recognition of indicial value in this geosite [24].

The name of the site (which means "mouth of Hell") came from a local legend that dates back to the slavery times. A plantation manager was so cruel and demonic that every time he wanted to travel to Portugal the local people thought that he disappeared by the channel that they believed to have a direct and instantaneous connection to the capital of the Kingdom. The return of this feared manager to São Tomé could happen at any moment, using the same way, and even today, the place is related to danger and fear, thus displaying typical symbolic value [24].

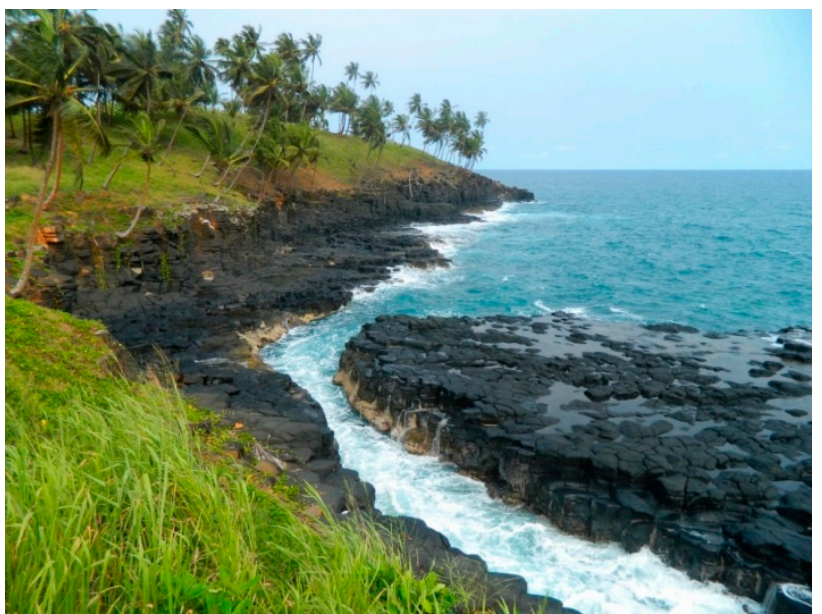

(a)

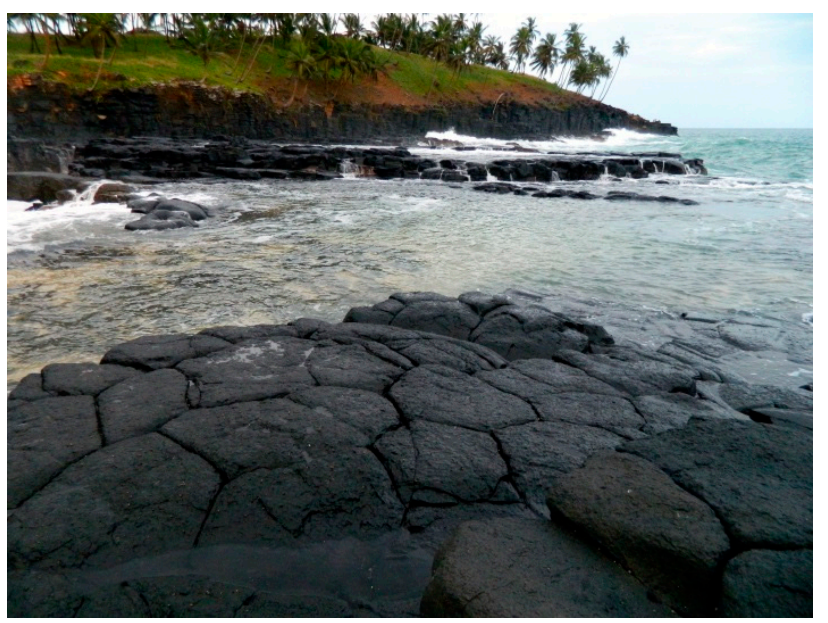

(b)

Figure 4. (a) The Boca do Inferno geosite; (b) The well-developed prismatic disjunction in basaltic lavas of the São Tomé Volcanic Complex.

\subsection{Pico do Cão Grande}

The Pico do Cão Grande ("big dog peak") is located on the south of the island, at Caué District (coordinates $0^{\circ} 7^{\prime} 05.17^{\prime \prime} \mathrm{N} ; 6^{\circ} 33^{\prime} 57.56^{\prime \prime} \mathrm{E}$ ), and integrates the Ôbo Natural Park, a subject of particular interest for its biodiversity ([26-30] and references therein). It corresponds to a $663 \mathrm{~m}$ high exhumed phonolitic chimney of $3 \mathrm{Ma}$ [15] belonging to the Volcanic Complex of Ribeira Afonso [20], thus displaying iconographic content [24]. Due to its scenic value, it is often depicted on postcards and stamps of the island; this elevation of volcanic origin is usually covered by a mist resulting from abundant annual rainfall (between 4500 and $5000 \mathrm{~mm}$ ), making the surface very slippery, but quite attractive for alpinists (Figure 5). 


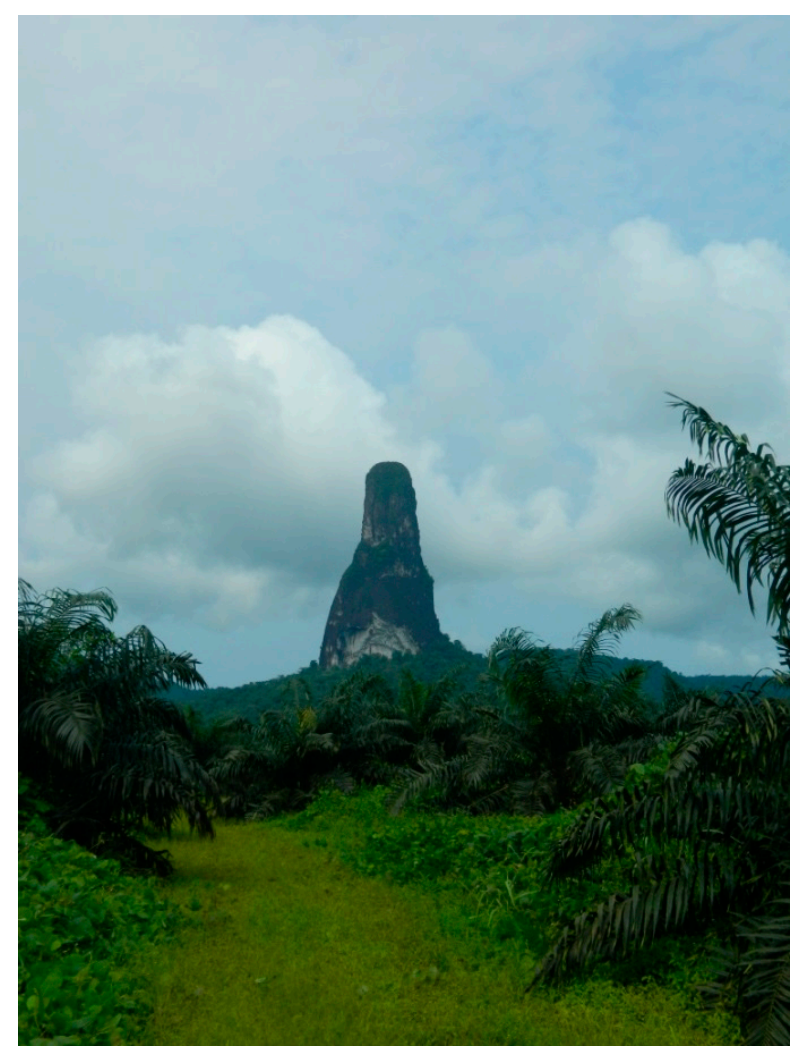

Figure 5. The Pico do Cão Grande, a phonolitic chimney of the Volcanic Complex of Ribeira Afonso.

\subsection{Lagoa Azul}

The Lagoa Azul ("blue lagoon") geosite is a small beach located approximately $17 \mathrm{~km}$ north of the city of São Tomé (Lobata District; coordinates $0^{\circ} 24^{\prime} 23.10^{\prime \prime} \mathrm{N} ; 6^{\circ} 36^{\prime} 36.53$ "E), and is also frequently depicted on postcards due to its scenic value [24]. Its waters of intense turquoise color houses one of the most important coral reefs of the island (Figure 6a). On the north flank of the beach is the Morro Carregado, which comprises pyroclastic materials of the São Tomé Volcanic Complex, sometimes displaying rhythmic stratification (Figure 6b); it corresponds to the earliest volcanic phase of the Complex $(<0.4 \mathrm{Ma})[17,18,20]$ and displays documental value [24].

\subsection{Nascente Queluz}

The Nascente Queluz ("Queluz spring") geosite is a spring of carbonated water related to the earliest volcanic phase of the São Tomé Volcanic Complex and is part of a group of similar springs (Madre de Deus, Boa Entrada, Pedra Maria, Potó, Caixão Grande and Palha) disposed along a NE-SW and NNE-SSW axis, the predominant directions of the volcanic edifices [20] and of the "Cameroon Volcanic Line". It is located at the Mé-Zochi District (coordinates $0^{\circ} 20^{\prime} 2.01^{\prime \prime} \mathrm{N} ; 6^{\circ} 38^{\prime} 45.54^{\prime \prime} \mathrm{E}$ ).

Recent analyses have shown that the waters are mainly of the $\mathrm{Ca} \pm \mathrm{Mg} \pm \mathrm{HCO}_{3}$ type, and that they result from $\mathrm{CO}_{2}$ solubilization in a shallow aquifer at low temperature, being of meteoric origin, with no discernible magmatic input [31]. The heritage content assignable to this geosite (iconographic) is related to specialized knowledge of particular geological phenomena (the hydrological cycle), usually perceived as exotic by non-specialists (Figure 7a). 
This water presents intense gasification, with an average temperature of $25^{\circ} \mathrm{C}$, a $\mathrm{pH}$ of 4.25 and a conductivity of $71 \mathrm{mS} / \mathrm{m}$, and is extensively used by the local population, mainly for consumption (Figure $7 b$ ). Being a highly socialized geosite largely used by the public due to reasons other than geological ones, the Nascente Queluz also displays symbolic value.

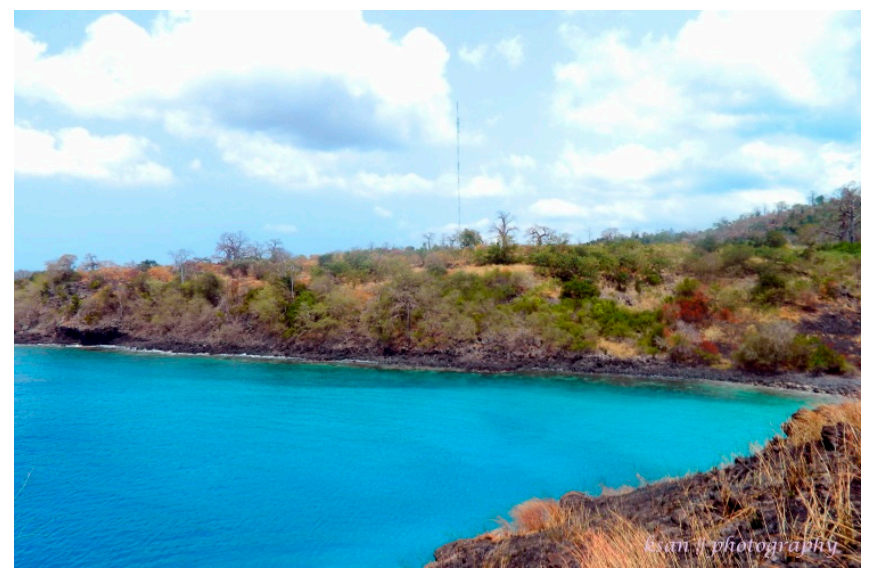

(a)

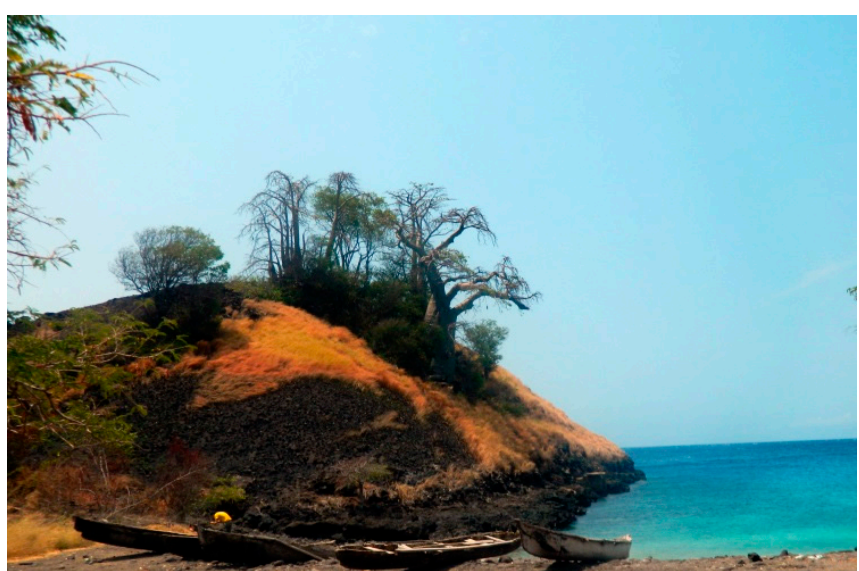

(b)

Figure 6. (a) The Lagoa Azul geosite, with its waters of intense turquoise color; (b) The Morro Carregado outcrop composed of pyroclastic materials of the São Tomé Volcanic Complex, and the $7 \mathrm{~m}$ high lighthouse, designed and built by the Portuguese Navy, and opened on 12 September 1997.

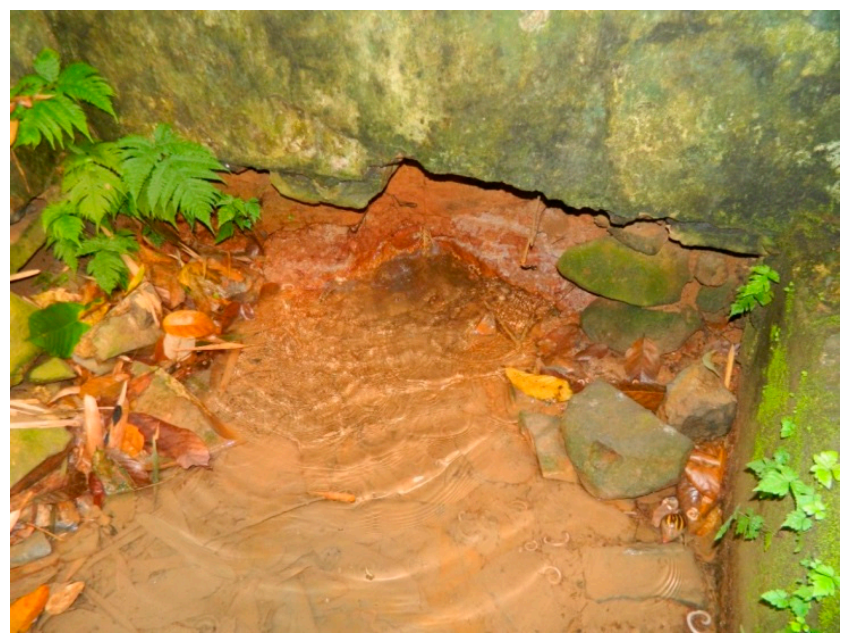

(a)

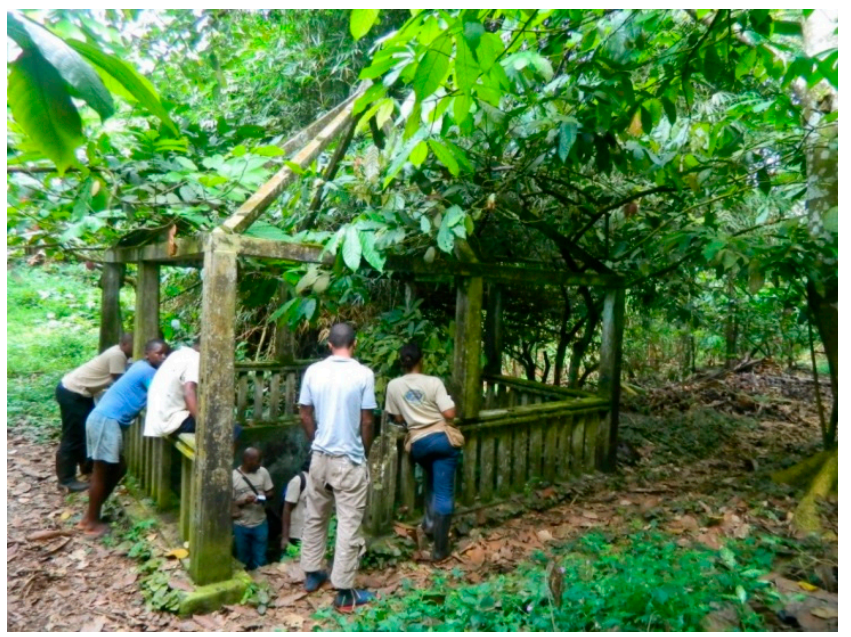

(b)

Figure 7. (a) Detail of the Nascente Queluz; (b) The Nascente Queluz geosite, provided with protective structure.

\subsection{Lagoa Amélia}

The Lagoa Amélia (“Amélia lagoon") geosite is fundamentally a structural surface, little affected by erosion, representing an ancient volcanic crater completely covered with vegetation, and is a typical object displaying indicial value (Figure 8). The geosite is located in the Mé-Zochi District, approximately 1 h 30 min walk from the road, at Bom Sucesso (coordinates $0^{\circ} 16^{\prime} 52.78^{\prime \prime} \mathrm{N}$; $6^{\circ} 35^{\prime} 26.28^{\prime \prime} \mathrm{E}$; altitude $1428 \mathrm{~m}$ ), in the Ôbo Natural Park. It corresponds to a phreatomagmatic crater 
whose activity is responsible for the well stratified and heterometric pyroclastic deposits containing abundant angular lithic fragments of basaltic and trachytic composition of the São Tomé Volcanic Complex [20]. As so, documental value can also be assigned to this geosite.

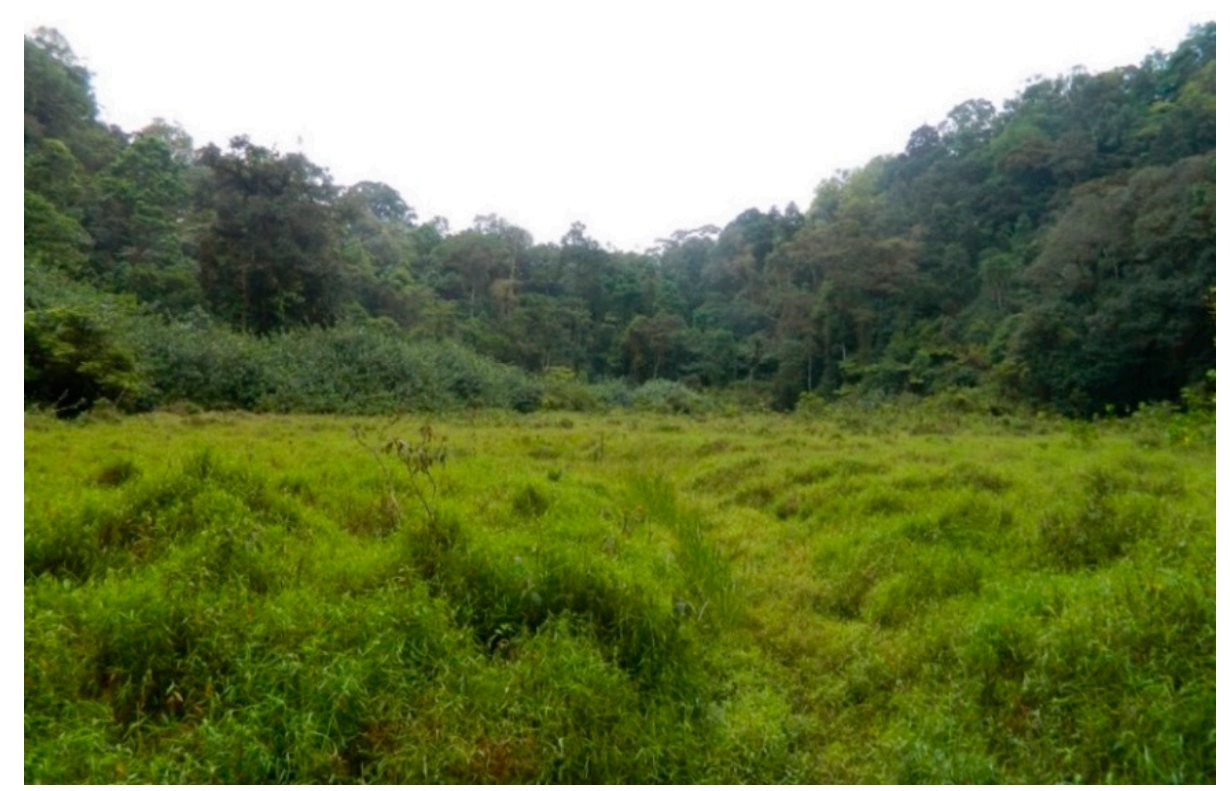

Figure 8. Panoramic view of Lagoa Amélia, a structural surface embedded in the crater of an extinct volcano.

Lagoa Amélia is a very unusual and mythical place filled with legends such as the one that its name originated from - "Amelia" was a young Portuguese girl that rushed there many years ago as a result of a tragic love - and, as such, it also displays symbolic value. Moreover, it is one of the best known and easily accessible places to observe mountain forest and corresponding avifauna, with altitudes ranging between $1200 \mathrm{~m}$ and $1500 \mathrm{~m}$.

\subsection{Ilhéu das Rolas}

The Ilhéu das Rolas ("islet of doves") geosite is located at the equator line (Caué District), a highly socialized place largely used by the tourists of the neighboring resort due to reasons other than geological ones, thus displaying symbolic content (Figure 9). It was formed by two recent, well-preserved volcanic cones that emitted lapilli-type pyroclasts and basaltic lavas (sometimes associated with scoriaceous lavas) during the latest phase of the São Tomé Volcanic Complex, dated $<0.4 \mathrm{Ma}[17,18,20]$. The lavas completely surround the two cones and they are mainly located below the present day sea level; the onshore portion slightly exceeds the $20 \mathrm{~m}$ altitude (in Ilhéu das Rolas) and can be observed on the coast where they give rise to low cliffs. For these reasons, this geosite also displays documental content. The belvedere located at the equator line provides high recreational function with its panoramic view over the facing Lama-Porco and S. Francisco volcanic cones located at the southern end of São Tomé Island, thus displaying scenic value [24]. It has a small monument supporting an armillary sphere that relies on a large polychrome pavement, with the representation of the world map, where the location of the equator is marked. 


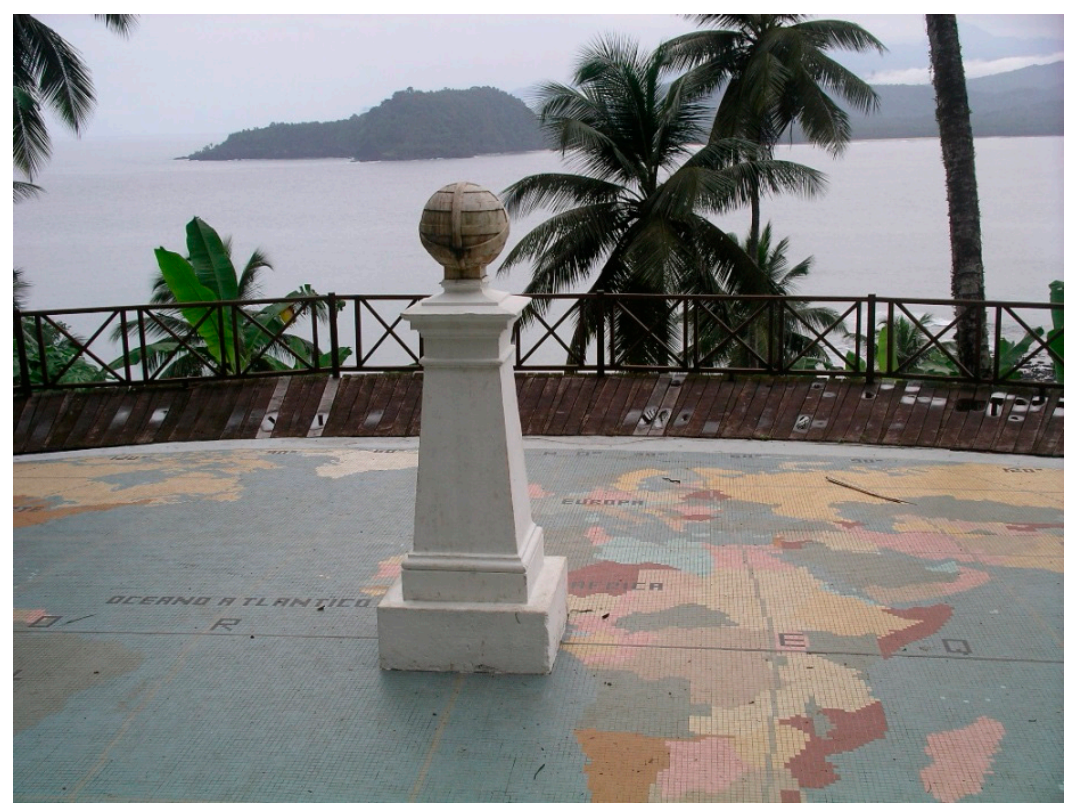

Figure 9. The Ilhéu das Rolas geosite, crossed by the equator line, which has a panoramic belvedere that provides a privileged view of the surrounding landscape.

\subsection{Túnel de Santa Catarina}

The Túnel de Santa Catarina ("Santa Catarina tunnel") is located at the west coast of the island (coordinates $0^{\circ} 18^{\prime} 32.46^{\prime \prime} \mathrm{N} ; 6^{\circ} 29^{\prime} 22.93$ "E; Lembá District) drilling an outcrop that extends to the beach, which is the only anthropogenic structure of this kind in the country (Figure 10). The outcrop shows lahar deposits intercalated in the basaltic lavas, which indicate discontinuities in the volcanic activity responsible for the formation of the São Tomé Volcanic Complex [20]. Iconographic content can be assigned to this geosite, considering that the lahar deposits, as a resulting structure of a particular geological phenomenon (volcanic mudflow), show clear physical relation between the event and its effects [24].

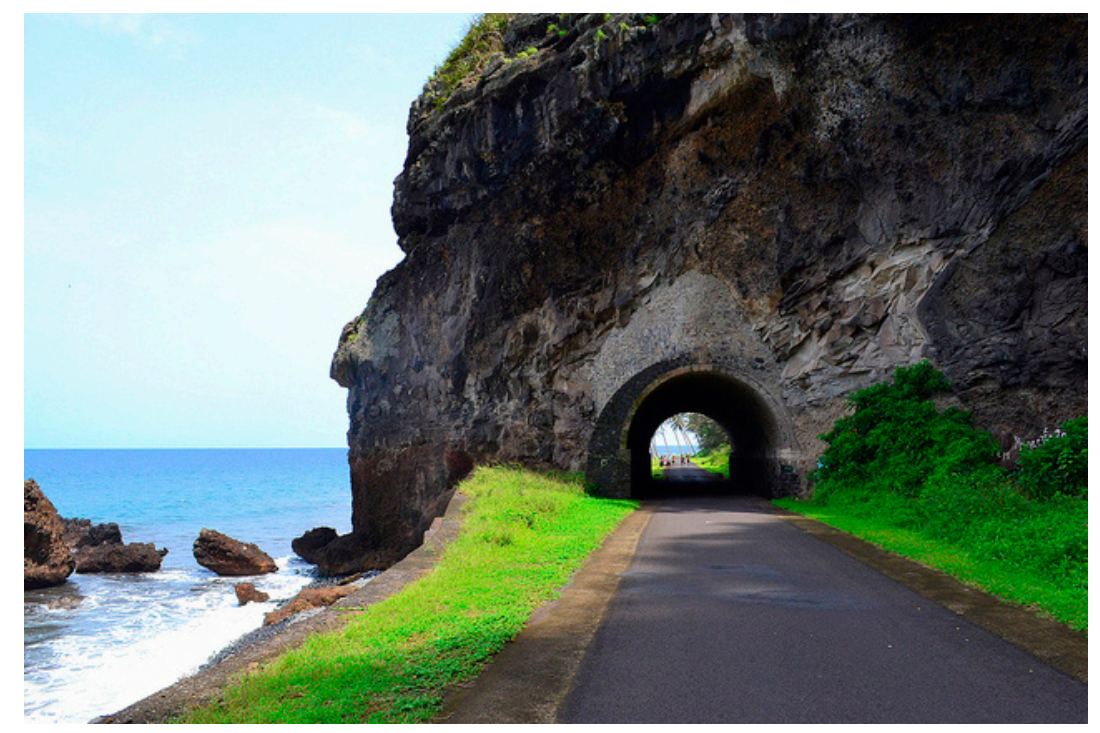

Figure 10. Sequence of basaltic lavas of the São Tomé Volcanic Complex at the west coastal cliffs of the island. 


\subsection{Ilhéu das Cabras}

The Ilhéu das Cabras ("islet of goats") has $1 \mathrm{~km}$ long by $250 \mathrm{~m}$ and is located $2 \mathrm{~km}$ NE of Cobo Beach (coordinates $0^{\circ} 24^{\prime} 26.90^{\prime \prime} \mathrm{N} ; 6^{\circ} 42^{\prime} 52.61^{\prime \prime} \mathrm{E}$; Água Grande District). It consists of two NE-SW direction trachytic hills, aligned with the Cameroon Volcanic Line; the one situated northeast reaches $80 \mathrm{~m}$ high (Figure 11). The outcrops forming this islet rise from the shallow abrasion platform as reliefs resulting of differential erosion of the massive structure and acid composition of the rocks. From a structural point of view, they represent one or two volcanic chimneys exhumed by erosion, forming the earliest known traces of volcanism responsible for the formation of the São Tomé Island (13 Ma ago) [1,20].

The Ilhéu das Cabras is the type-locality of the Volcanic Formation of Ilhéu das Cabras (13 Ma), a highly demonstrative record particularly relevant for the understanding of the geological history of São Tomé [1,2,17-20], and hence it presents documental value [24].

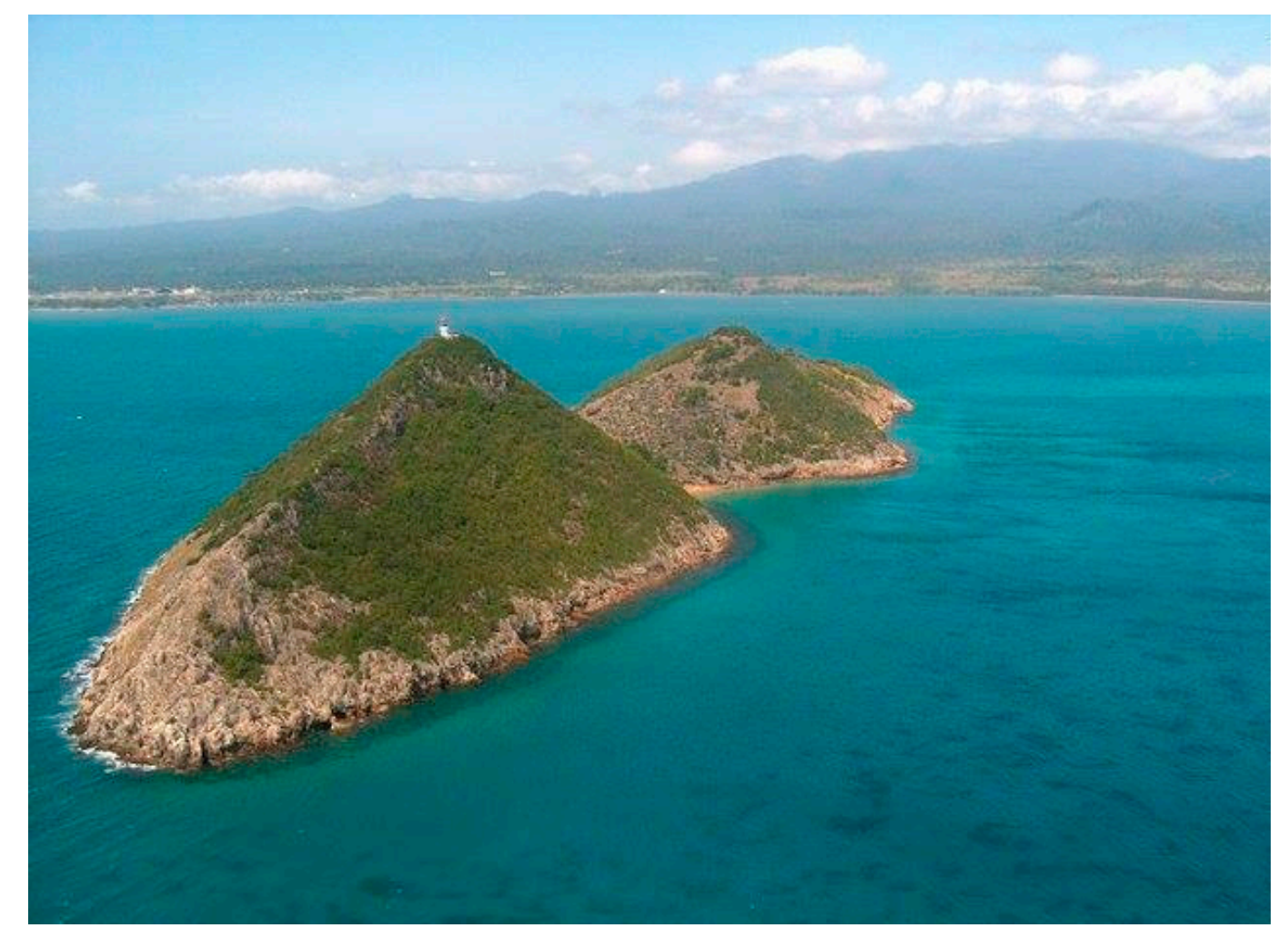

Figure 11. Aerial view of the Ilhéu das Cabras geosite showing the two trachytic reliefs, aligned with the NE-SW direction of the Cameroon Volcanic Line.

\subsection{Pico de São Tomé}

The Pico de São Tomé ("São Tomé peak") is located in the northern part of the Ôbo Natural Park, in an eccentric position, northwest of the geographic center of the island (coordinates $0^{\circ} 16^{\prime} 10.48^{\prime \prime} \mathrm{N}$; $6^{\circ} 32^{\prime 2} 28.78^{\prime \prime} \mathrm{E}$; Lembá District). The relief is characterized by a continuous and regular ascent from the coast to the line of greatest elevation, which reaches $2024 \mathrm{~m}$ (Figure 12a,b). Interpreted as a shield volcano that, being deeply carved by fluvial erosion, stands very rough. The relief of the Pico de São Tomé is related to the fissure volcanism type of the main and latest volcanic phase of the São Tomé Volcanic Complex that covers the central and northwestern part of the island [18]. Besides its 
documental and landscape value, by representing the highest point of the island and the country this geosite also possesses symbolic and scenic value [24].

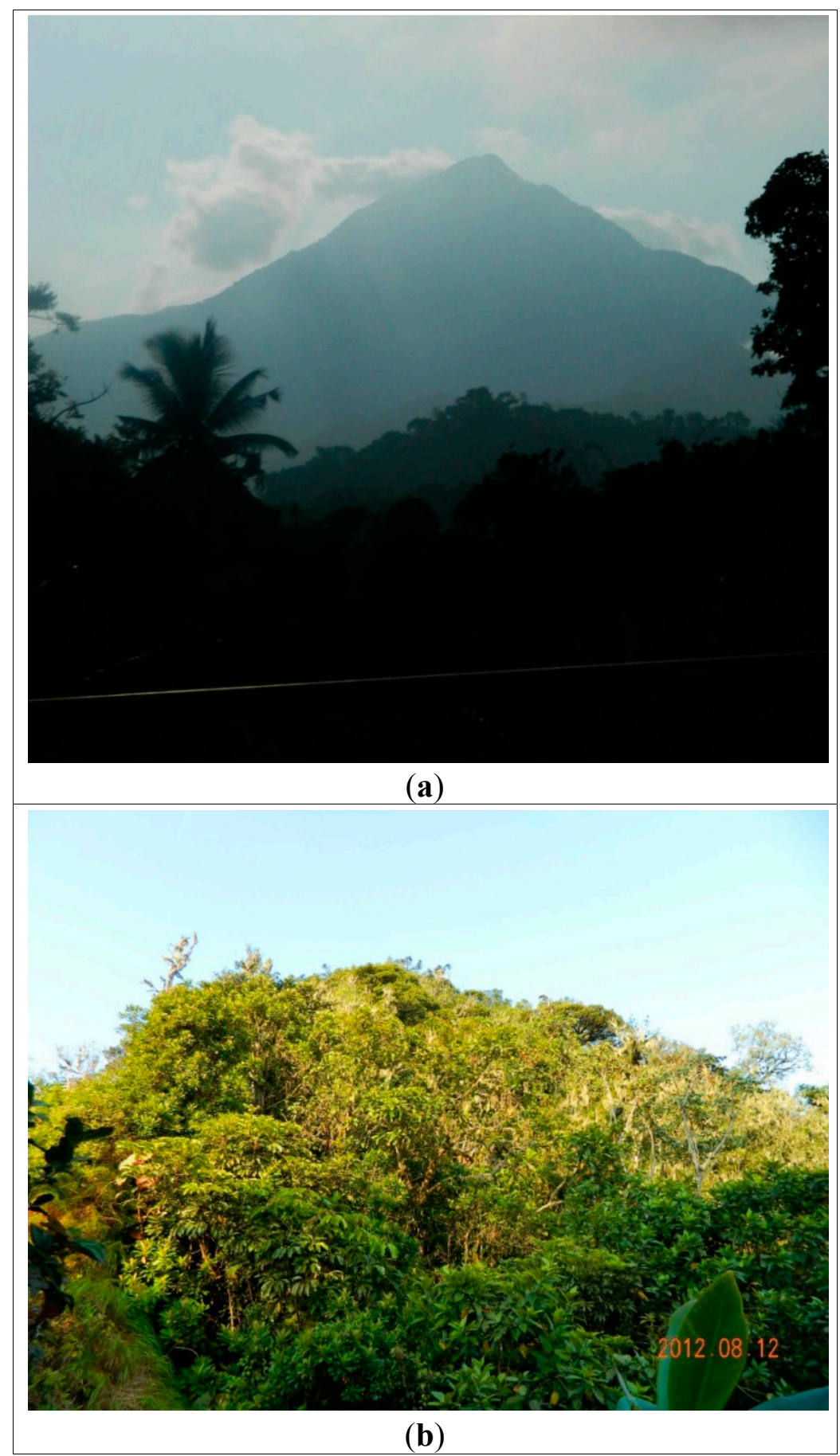

Figure 12. (a) The Pico de São Tomé observed from the bridge of Rio Lembá; (b) The top of Pico de São Tomé observed from the peak table.

\subsection{Qualitative Evaluation of the São Tomé Geoheritage}

The scope of geoconservation is the conservation of geosites, by means of specific inventory, evaluation, conservation, valuing and monitoring procedures [32]. Inventory and evaluation procedures are major steps on the implementation of subsequent conservation, valuing and monitoring actions of 
the geological heritage [12]. The geoheritage value recognized in the 10 selected geosites of São Tomé Island are diverse, including geological objects with local and regional relevance when evaluated from a scientific perspective (geosites 1, 2, 4, 6, 7, 9 and 10). However, many of them also have other features with heritage value, related to the potential for been appreciated by non-specialists on earth sciences, namely those displaying scenic and symbolic (geosites 1, 2, 3, 4, 5, 7 and 10).

Moreover, most of the selected geosites display more than one type of value, the heritage value then being substantially increased, as well as the need for implementing measures that ensure its physical integrity. Priority in geoconservation measures can be determined on the basis of the heritage value obtained through the global qualitative assessment of each geosite (sum of ranks) and its vulnerability to natural and anthropic threats (Figure 13 and Table 2).

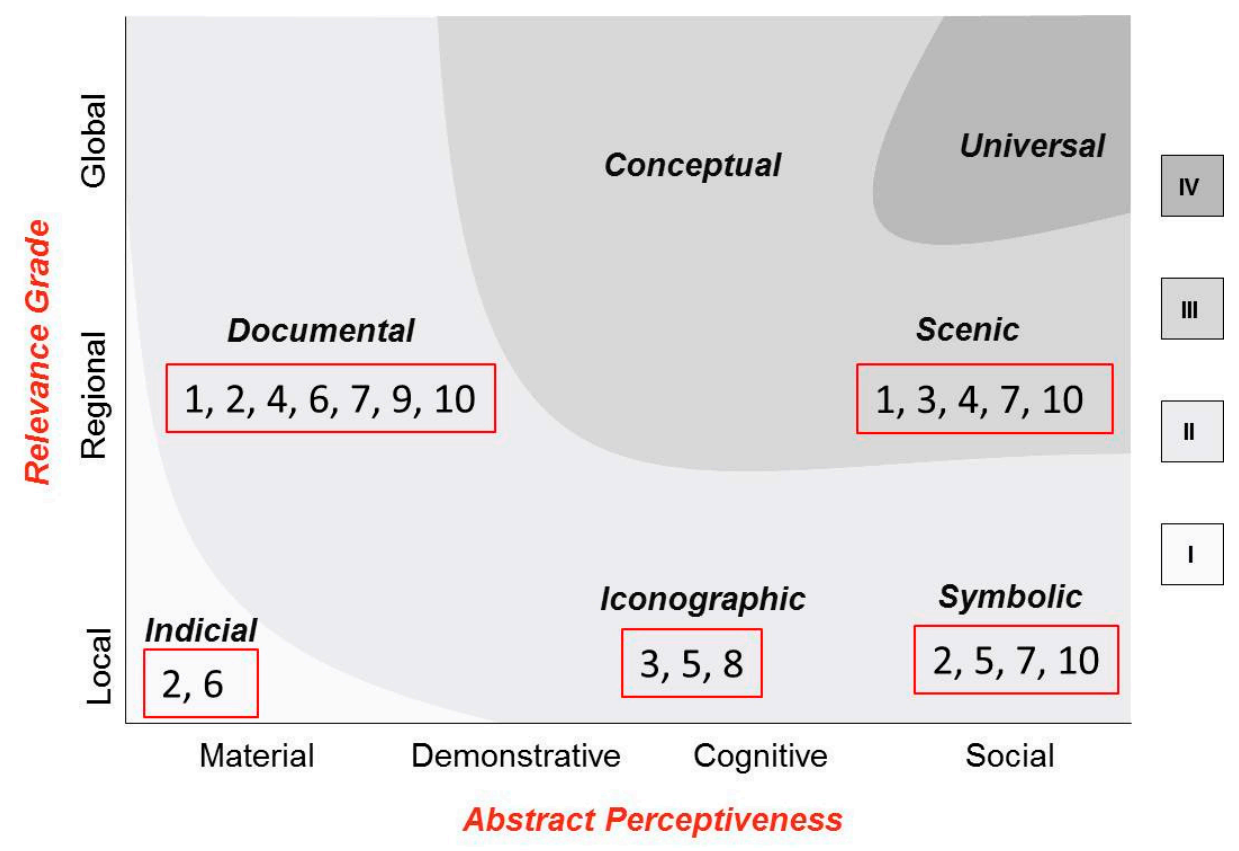

Figure 13. Heritage values of São Tomé geosites. Most of the geosites display more than one type of value, its heritage value being then substantially increased.

The Ilhéu das Rolas and Pico de São Tomé represent geosites holding the most heritage value on the island. The first one is only accessible by boat and has a 4-star resort which assumes social responsibility in their activities [33]; the second one is already included in a protected area with $235 \mathrm{~km}^{2}$ surface (the Ôbo Natural Park), mainly focused on the preservation of biodiversity [34]. Geoconservation measures for these geosites include classification, valuing and monitoring procedures. The Túnel de Santa Catarina and Ilhéu das Cabras geosites are qualified within the lowest ranks. The first one is mainly of interest for educational purposes; it has good accessibility for fieldwork activities with students, and can be used as an educational resource of great importance in promoting education for sustainable development, mobilizing knowledge inherent to the Earth Sciences [35]. Besides classification, valuing - through the elaboration of interpretative panels and field guides other than generalist ones ([36,37], among others) — and monitoring procedures are particularly important geoconservation actions for this geosite. The second one is a small inhabited islet, only accessible by boat, and interesting mainly for academic studies. Classification and monitoring can be enough in this case. 
Table 2. Qualitative evaluation of the São Tomé geosites necessary to support geoconservation initiatives that ensures their physical integrity.

\begin{tabular}{|c|c|c|c|c|}
\hline & Geosite & Geoheritage Contents & Qualitative Assessment & Geoconservation Priority \\
\hline (1) & $\begin{array}{l}\text { Cascata do Rio } \\
\text { do Ouro }\end{array}$ & $\begin{array}{l}\text { Documental } \\
\text { Scenic }\end{array}$ & $\begin{array}{l}\text { Rank II } \\
\text { Rank III }\end{array}$ & $2 \mathrm{nd}$ \\
\hline (2) & Boca do Inferno & $\begin{array}{l}\text { Indicial } \\
\text { Documental } \\
\text { Symbolic } \\
\end{array}$ & $\begin{array}{l}\text { Rank I } \\
\text { Rank II } \\
\text { Rank II } \\
\end{array}$ & 2nd \\
\hline (3) & $\begin{array}{l}\text { Pico do Cão } \\
\text { Grande }\end{array}$ & $\begin{array}{l}\text { Iconographic } \\
\text { Scenic }\end{array}$ & $\begin{array}{l}\text { Rank II } \\
\text { Rank III } \\
\end{array}$ & 2nd \\
\hline (4) & Lagoa Azul & $\begin{array}{l}\text { Documental } \\
\text { Scenic }\end{array}$ & $\begin{array}{l}\text { Rank II } \\
\text { Rank III }\end{array}$ & $2 \mathrm{nd}$ \\
\hline (5) & Nascente Queluz & $\begin{array}{l}\text { Iconographic } \\
\text { Symbolic }\end{array}$ & $\begin{array}{l}\text { Rank II } \\
\text { Rank II } \\
\end{array}$ & $3 r d$ \\
\hline (6) & Lagoa Amélia & $\begin{array}{l}\text { Indicial } \\
\text { Documental }\end{array}$ & $\begin{array}{l}\text { Rank I } \\
\text { Rank II }\end{array}$ & $3 \mathrm{rd}$ \\
\hline (7) & Ilhéu das Rolas & $\begin{array}{l}\text { Documental } \\
\text { Symbolic } \\
\text { Scenic } \\
\end{array}$ & $\begin{array}{l}\text { Rank II } \\
\text { Rank II } \\
\text { Rank III } \\
\end{array}$ & 1 st \\
\hline (8) & $\begin{array}{l}\text { Túnel de } \\
\text { Santa Catarina }\end{array}$ & Iconographic & Rank II & 4 th \\
\hline (9) & Ilhéu das Cabras & Documental & Rank II & 4th \\
\hline (10) & Pico de São Tomé & $\begin{array}{l}\text { Documental } \\
\text { Symbolic } \\
\text { Scenic }\end{array}$ & $\begin{array}{l}\text { Rank II } \\
\text { Rank II } \\
\text { Rank III }\end{array}$ & 1 st \\
\hline
\end{tabular}

\subsection{Geotourism Potential of São Tomé}

The São Tomé geosites characterized and evaluated in the present work, being notable representatives of natural heritage, can be considered as a geotouristic destination and, as so, they must be protected by nature conservation and land-use planning policies [38]. Such task depends mainly on the political will of local leaders, which is reflected in the strategic development options for the country.

Tourism is an economic activity with the greatest potential of this small African state, namely the emerging nature tourism, ecotourism, scientific tourism, watching tourism, and supportive and socially responsible tourism [39]. Geotourism as geological and geomorphologically-focused sustainable tourism [40] can play a key role in the promotion of sustainable development in the Democratic Republic of São Tomé and Príncipe, ranked 144 out of 186 on the 2013 Human Development Index [41]. The initiation and development of geotourism and geoconservation in this country can be designed through a Local Geodiversity Action Plan, as proposed for a similar context in the Mauritius, which includes an inventory of geosites, tourism analysis, a programme of stakeholder collaboration and geotourism product development [42]. Earth scientists are crucial in inventory activities and subsequent evaluation and classification of geosites as the value of the sites can only be fully understood through professional interpretation of the observed features [43]; their expertise is also required to support geotourism activities leading to tourist satisfaction - e.g., as advisors in the implementation of education/interpretative 
programmes and elaboration of specific resources such as interpretative panels and geo-itineraries, as already started and which are mainly aimed at schoolchildren, to whom geosites 2 and 5 are particularly appropriate [44].

Many geosites of São Tomé Island display heritage contents which can meet different tourist expectations. The non-specialized public (1, 3, 4, 7 and 10), as well as geotourists with a strong scientific background (6, 8 and 9), can enrich their travelling experience to the island by visiting the appropriate geosites; as so, the inclusion of each geosite in geo-itineraries should take into account their main potential use (Figure 14).

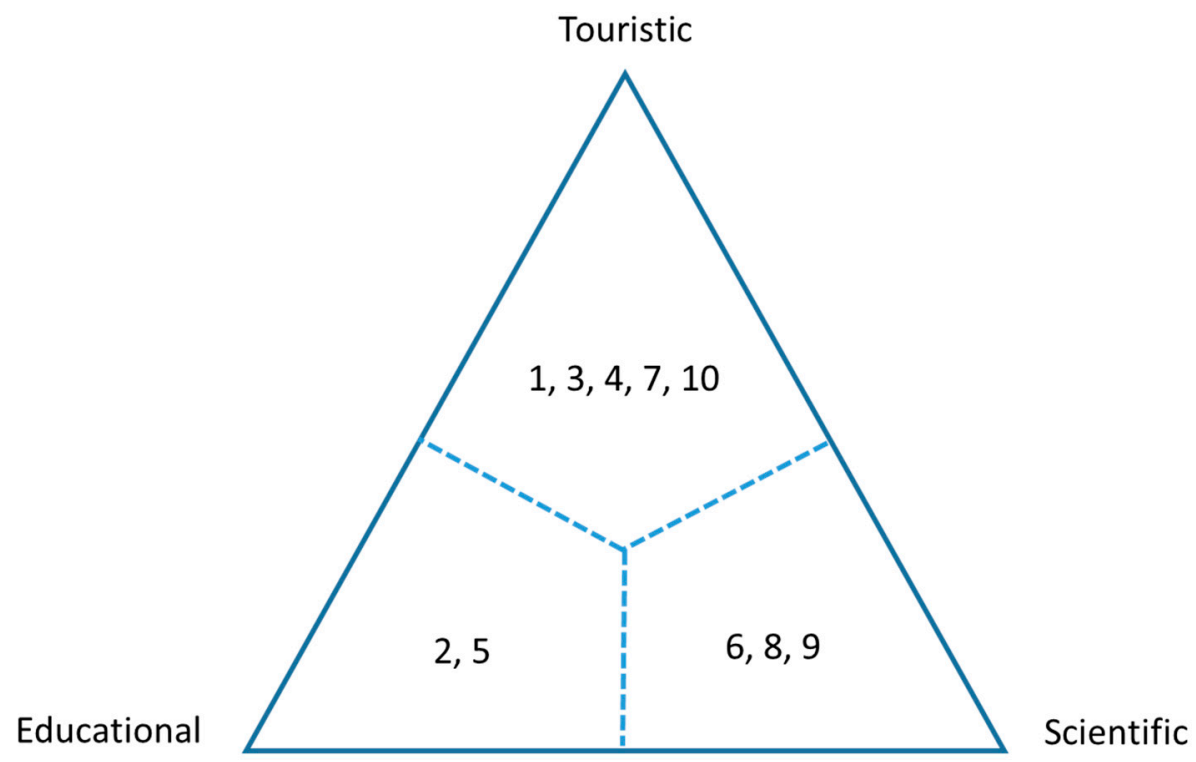

Figure 14. Main potential use of each São Tomé geosite described in the present work.

\section{Conclusions}

Africa is the continent with the deepest and richest geological, biological and cultural heritage [10], boasting the world's geodiversity hotspot [32]. However, Africa has only 89 (9\%) properties in the World Heritage List of UNESCO (48 cultural sites, 37 natural sites and four mixed sites) inscribed by 33 State Parties [45]. So far, the Democratic Republic of São Tomé and Principe is not included in such list, despite that the biodiversity of the isle of Príncipe has already been recognized by UNESCO through the Man and the Biosphere Programme [8]. The particular location of this small volcanic archipelago in the oceanic sector of the "Cameroon Volcanic Line" makes its outcrops subject of interest to the scientific community. The representativeness and uniqueness of some give them heritage value, as supported in this work, where 10 geosites of the São Tomé Island were selected, described and evaluated on the basis of the heritage values they display: Cascata do Rio do Ouro, Boca do Inferno, Pico de Cão Grande, Lagoa Azul, Nascente Queluz, Lagoa Amélia, Ilhéu das Rolas, Túnel de Santa Catarina, Ilhéu das Cabras, and Pico de São Tomé. When analyzed from a strictly academic perspective, they correspond to sites with volcanological and hydrological heritage, besides geomorphological, i.e., geomorphosites [13].

Using a qualitative system of classification which integrates both the meaning attributed to the objects by scientific communities ("grade of relevance") and the public understanding of such meanings related 
to its social use ("abstract perceptiveness"), the selected geosites display different heritage values which can be ranked into three categories of increasing importance: rank I—indicial value; rank II—documental, iconographic, and symbolic value; and rank III — conceptual and scenic value.

Most of the geosites have more than one type of value, its heritage value being then substantially increased, as well the need to implement appropriate measures to ensure their integrity. Moreover, the selected geosites are potentially usable for different purposes, namely scientific and educational, but mostly tourism. This is the case of Cascata do Rio do Ouro, Pico do Cão Grande, Lagoa Azul, Ilhéu das Rolas and Pico de São Tomé geosites, all displaying, among others, scenic value, an important requirement to support tourism activities.

Geotourism is an emergent type of tourism "which sustains and enhances the identity of a territory, taking into consideration its geology, environment, culture, aesthetics, heritage and well-being of its residents" [46]. This economic activity fosters geoheritage conservation through appropriate sustainability measures that increase the public understanding of the history of Life on Earth, including its dynamics and mechanisms, through interpretation and education [5]. It can also represent an important income for local communities if they become involved in the promotion of São Tomé geological attractions as geo-tour guides, thus enriching an incipient nature-based tourism already in progress on the archipelago. The 10 geosites characterized and evaluated in the present work are likely to constitute the basis for the elaboration of one or several different geo-itineraries potentially satisfactory to a wide range of geotourist preferences, from specialized to non-specialized visitors. The required local support for its implementation, although difficult to achieve, would represent an important commitment towards the geoconservation of this "pearl" of the Cameron Line, a milestone of the Gondwana story that all 900 million Africans of every background and persuasion are aimed to draw "into co-curating, co-documenting and together keeping alive their continent's unmatched heritage — an epic and unfolding story" [47].

\section{Author Contributions}

The two authors contributed equally to this work. Maria Helena Henriques designed the research which was performed by Keynesménio Neto. The data were analysed by Maria Helena Henriques, who also wrote the paper that includes maps and photos made by Keynesménio Neto. All authors read and approved the final manuscript.

\section{Conflicts of Interest}

The authors declare no conflict of interest.

\section{References}

1. Fitton, J.G.; Dunlop, H.M. The Cameroon Line, West Africa and its bearing on the origin of oceanic and continental alkali basalt. Earth Planet. Sci. Lett. 1985, 72, 23-38.

2. Fitton, J.G. The Cameroon Line, West Africa: A comparison between oceanic and continental alkaline volcanism. In Alkaline Igneous Rocks; Fitton, J.G., Upton, B.G.J., Eds.; Geological Society Special Publication: London, UK, 1987; Volume 30, pp. 273-291. 
3. Toteu, S.F.; Anderson, J.M; de Wit, M. "Africa Alive Corridors": Forging a new future for the people of Africa by the people of Africa. J. Afr. Earth Sci. 2010, 58, 692-715.

4. Tefogoum, G.Z.; Dongmo, A.K.; Nkouathio, D.G.; Wandji, P.; Dedzo, M.G. Geomorphological features of the Manengouba Volcano (Cameroon Line): Assets for potential geopark development. Geoheritage 2014, 6, 225-239.

5. Dowling, R.K. Geotourism's Global Growth. Geoheritage 2012, 3, 1-13.

6. Reimold, W.U. Geoconservation-A southern African and African perspective. J. Afr. Earth Sci. 1999, 29, 469-483.

7. Henriques, M.H. Jurassic Heritage of Portugal: State of the art and open problems. Riv. Ital. Paleontol. Stratigr. 2004, 110, 389-392.

8. UNESCO. Natural Sciences. Environment. Ecological Sciences. Biosphere Reserves. Sao Tome and Principe. Available online: http://www.unesco.org/new/en/natural-sciences/environment/ ecological-sciences/biosphere-reserves/africa/sao-tome-and-principe/the-island-of-principe/ (accessed on 13 October 2014).

9. Jones, P.J. Biodiversity in the Gulf of Guinea. Biodivers. Conserv. 1994, 3, 772-784.

10. Peet, N.B.; Atkinson, P.W. The biodiversity and conservation of the birds of São Tomé and Príncipe. Biodivers. Conserv. 1994, 3, 851-867.

11. Dowling, R.K. Geotourism Global Grow. Geoheritage 2011, 3, 1-13.

12. Henriques, M.H.; Pena dos Reis, R.; Brilha, J.; Mota, T. Geoconservation as an Emerging Geoscience. Geoheritage 2011, 3, 117-128.

13. Panizza, M. Geomorphosites: Concepts, methods and examples of geomorphological survey. Chin. Sci. Bull. 2001, 46, 4-5.

14. Martínez-Frías, J.; Mogessie, A. The need for a geoscience education roadmap for Africa. Episodes 2012, 35, 489-492.

15. Henriques, M.H.; Andrade, A.I.S.; Lopes, F.C. The Earth Sciences among the Community of Portuguese-Speaking countries and the future of Gondwana. Episodes 2013, 36, 255-262.

16. Njonfang, E.; Nono, A.; Kamgang, P.; Ngak, V.; Tchoua, F.M. Cameroon Line alkaline magmatism (Central Africa): A reappraisal. Geol. Soc. Am. Spec. Paper 2011, 478, 173-191.

17. Halliday, A.N.; Dickin, A.P.; Fallick, A.E.; Fitton, J.G. Mantle Dynamics: A Nd, Sr, Pb and O isotopic study of the Cameroon Line Volcanic Chain. J. Petrol. 1988, 29, 181-211.

18. Munhá, J.M.; Afonso, R.S.; Caldeira, R.; Mata, J. Estudo geológico preliminar da Região Nordeste da ilha de S. Tomé (folha no. 2-Ana Chaves). Garcia Orta-Sér. Geol. 2002, 18, 1-8.

19. Caldeira, R.; Munhá, J.M. Petrology of ultramafic nodules from São Tomé Island, Cameroon Volcanic Line (oceanic sector). J. Afr. Earth Sci. 2002, 34, 231-246.

20. Caldeira, R.; Madeira, J.; Munhá, J.M.; Afonso, R.S.; Mata, J.; Tassinari, C.C.; Nascimento, E. Caracterização das principais unidades volcano-estratigráficas da ilha de São Tomé, Golfo da Guiné. Available online: http://socgeol.org/documents/vi-congresso-nacional-de-geologia-caparica2003 (accessed on 5 January 2015).

21. Aka, F.T.; Nagao, K.; Kusakabe, M.; Sumino, H.; Tanyileke, G.; Ateba, B.; Hell, J. Symmetrical Helium isotope distribution on the Cameroon Volcanic Line, West Africa. Chem. Geol. 2004, 203, 205-223. 
22. Fassoulas, C.; Mouriki, D.; Dimitriou-Nikolakis, P.; Iliopoulos, G. Quantitative Assessment of Geotopes as an Effective Tool for Geoheritage Management. Geoheritage 2012, 4, 177-193.

23. Reynard, E.; Coratza, P. Scientific research on geomorphosites. A review of the activities of the IAG working group on geomorphosites over the last twelve years. Geogr. Fis. Dinam. Quat. 2013, $36,159-168$.

24. Pena dos Reis, R.; Henriques, M.H. Approaching an Integrated Qualification and Evaluation System for Geological Heritage. Geoheritage 2009, 1, 1-10.

25. Henriques, M.H.; Tavares, A.O.; Bala, A.L.M. The geological heritage of Tundavala (Angola): An integrated approach to its characterization. J. Afr. Earth Sci. 2013, 88, 62-71.

26. Mesterházy, A.; Browning, J. A rare enigmatic sedge rediscovered: Principina grandis (Cyperaceae) newly recorded from São Tomé. Kew Bull. 2014, 69, 1-4.

27. Lachaise, D.; Chassagnard, M.-T. Divergence of sex comb phenotypes in the Drosophila fima species group and radiation on Afrotropical Ficus, including five new species from East Africa and Madagascar (Diptera: Drosophilidae). Ann. Soc. Entomol. Fr. 2002, 38, 79-99.

28. Csuzdi, C. Earthworms (Annelida: Oligochaeta) of Sao Tomé. J. Nat. Hist. 2005, 39, 3039-3058.

29. Enroth, J.; Shevock, J.R. Porotrichum saotomense sp. nov. (Neckeraceae) and other additions to the moss flora of São Tomé \& Príncipe, Gulf of Guinea, West Africa. Trop. Bryol. 2011, 33, 6-11.

30. Russoa, D.; Maglioc, G.; Rainhod, A.; Meyerd, C.F.J.; Palmeirimd, J.M. Out of the dark: Diurnal activity in the bat Hipposideros ruber on São Tomé Island (West Africa). Mamm. Biol. Z. Säugetierkd. 2001, 76, 701-708.

31. Aka, F.T.; Kusakabe, M.; Nagao, K.; Tanyileke, G. Noble gas isotopic compositions and water/gas chemistry of soda springs from the islands of Bioko, São Tomé and Annobon, along with Cameroon Volcanic Line, West Africa. Appl. Geochem. 2001, 16, 323-338.

32. Brilha, J. Património Geológico e Geoconservação. A Conservação da Natureza na sua Vertente Geológica; Palimage: Braga, Portugal, 2005; pp. 1-183.

33. Pestana Hotels and Resorts. Available online: http://www.pestana.com/pt/institucional/ sustentabilidade/responsabilidade-social/africa/pages/outras-accoes.aspx (accessed on 23 October 2014).

34. Obo Natural Parks. Available online: http://www.obopark.com/en/saotomeprincipe/ nationalparks.html (accessed on 23 October 2014).

35. Henriques, M.H.; Tomaz; C.; Sá, A. The Arouca Geopark (Portugal) as an educational resource: A case study. Episodes 2012, 35, 481-488.

36. Becker, K. São Tomé and Príncipe; The Bradt Travel Guides: Bucks, UK, 2008; pp. 1-232.

37. Warne, S. Gabon, São Tomé and Príncipe; The Bradt Travel Guides: Bucks, UK, 2003; pp. 1-244.

38. Brilha, J. Geoconservation and protected areas. Environ. Conserv. 2002, 29, 273-276.

39. Brito, B.R. Turismo em meio insular africano: Análise comparativa de impactos. Tourism in the African insular environment: A comparative analysis of impacts. Ambient. MENTE Sustentable 2010, $I, 157-177$.

40. Hose, T. 3 G's for modern geotourism. Geoheritage 2012, 4, 7-24.

41. World Food Programme. São Tomé and Principe. Available online: https://www.wfp.org/ countries/s\%C3\%A3o-tom\%C3\%A9-and-principe/overview (accessed on 23 October 2014). 
42. Newsome, D.; Johnson, C.P. Potential Geotourism and the Prospect of Raising Awareness About Geoheritage and Environment on Mauritius. Geoheritage 2013, 5, 1-9.

43. Bruno, D.E.; Crowley, B.E.; Gutak, J.M.; Moroni, A.; Nazarenko, O.V.; Oheim, K.B.; Ruban, D.A.; Tiess, G.; Zorina, S.O. Paleogeography as geological heritage: Developing geosite classification. Earth-Sci. Rev. 2014, 138, 300-312.

44. Oliveira, M; Santos, O. Património Natural de São Tomé e Príncipe. Conhecer Para Preservar...; Instituto Marquês de Valle Flôr: Leiria, Portugal, 2013; pp. 1-12.

45. UNESCO World Heritage Centre. World Heritage List Statistics. Number of World Heritage Properties by Region. Available online: http://whc.unesco.org/en/list/stat\#d1 (accessed on 20 November 2014).

46. Arouca Declaration. International Congress Arouca 2011. Geotourism in Action. Available online: https://dl.dropboxusercontent.com/u/36358978/News/Declaration_Arouca_\%5BEN\%5D.pdf (accessed on 24 November 2014).

47. De Wit, M.J.; Anderson, J.M. Gondwana Alive Corridors: Extending Gondwana Research to Incorporate Stemming the Sixth Extinction. Gondwana Res. 2003, 6, 369-408.

(C) 2015 by the authors; licensee MDPI, Basel, Switzerland. This article is an open access article distributed under the terms and conditions of the Creative Commons Attribution license (http://creativecommons.org/licenses/by/4.0/). 